\title{
SOUTHEAST ASIAN REGION MARITIME CONNECTIVITY AND THE POTENTIAL DEVELOPMENT OF THE NORTHERN SEA ROUTE FOR COMMERCIAL SHIPPING
}

\author{
Hanizah Idris* \& Muhammad Faiz Ramli \\ ( ${ }^{*}$ First author) \\ Department of Southeast Asian Studies, Faculty of Arts and Social Sciences, \\ University of Malaya \\ (wafa@um.edu.my, fareastramly@gmail.com) \\ DOI: https://doi.org/10.22452/jati.vol23no2.2
}

\begin{abstract}
Today the Suez Canal remains the traditional sea route where cargoes transported between the Far East and Europe, and vice versa. However, the most important international waterway is the Straits of Malacca situated in the Southeast Asian region where it is estimated more than 80,000 vessels are plying through the straits annually. There was recently an interest to venture into a new route namely the Northern Sea Route (NSR) as an alternative route between Europe, and the Far East and vice versa. This paper aims to explain the background of the international trade and shipping at the Straits of Malacca. Secondly, to explain the importance of the NSR in facilitates commercial shipping and trade in the Artic Region. Thirdly, to analyses the NSR's commercial potential and economic importance as an alternative route for commercial shipping and trade with Asian Region and finally to analyses the challenges and constraints of the NSR including the physical aspects of the route which is in ice conditions most of the time around a year. Findings show that Singapore had shown its interest by becoming a member of the Artic Council, while other countries in the region including Malaysia needs to take into consideration the potential of the NSR as an alternative shipping route in the future to overcome some long-standing issues related to the traffic congestion at the Straits of Malacca.
\end{abstract}

Keywords: maritime connectivity, Southeast Asia, Northern Sea Route, commercial shipping, port infrastructure 


\section{Introduction}

Southeast Asia region is strategically located at the crossing of the Indian Ocean and the South China Sea. The region is home of importance oceans, seas, and straits that formed one of the busiest international sea lines of communications (SLOCs). The South China Sea and the Straits of Malacca play a vital role in the international trade and shipping and considered chokepoints in the system of SLOCs. The region is also considered as one of the richest biodiversity areas, a center of gravity for a wider Asia-Pacific region and rich with oil. Off the 87 barrels of oil produced per day in 2011, approximately 15.2 million passed through the Straits of Malacca, the shortest route between Africa and Persian Gulf suppliers and Asian market. This is some 19 percent the amount passed through the Panama Canal and four times more than the volume passed through the Suez Canal over the same period. Maritime Southeast Asia is always important as a center of trading and shipping activities. Economies of scale have given development trends in world shipping which focusing on container handling.

Today, Asian container trade accounted for an almost 60 percent share of world container throughput with East Asia as the dominant sub-region while Singapore and Malaysia are the best-connected ports in Southeast Asia via Straits of Malacca. Containerization completely changed the world's commercial geography with the emergence of an array of new port locations, the top being Asia Pacific ports along to Tokyo-Singapore corridor, notably Chinese ports, surged. In the meanwhile, the Northern Sea Route (NSR) is only significant for arctic shipping with limited access. However, in terms of maritime connectivity, there is a possibility to open the sea route for commercial shipping activities in the near future where the NSR was identified as an alternative sea route to the traditional links via Suez and Panama between the Atlantic and the Pacific.

Therefore, this paper attempts to examine the maritime connectivity in the Southeast Asian region and NSR regarding its potential for commercial shipping and port developments. It will be examined in three aspects, first, in the context of maritime connectivity in the Southeast Asian region, secondly, the maritime activity on the NSR, and finally, the potential development of NSR as a commercial shipping route. A study on the Arctic trade is relatively new especially to countries with a status of none arctic state like Malaysia. For a long time, Arctic Region is only significant to those arctic coastal states like Russia, Norway, Canada, Sweden and Finland and the interest on it was minimal. 
Today, with the change in climate, maritime trading nations, especially in Europe and East Asia, had shown their interest in exploring the possibility of using the NSR for commercial shipping. Globally, with a new political willingness, Singapore already accepted as a Permanent Observer at the Arctic Council in May 2013 along with Japan and Korea. Eventually, this will open up new involvement from other Asian countries including Malaysia in terms of research and the possibility of getting involved in the Arctic trade in the future by analyzing the above aspects.

Geographically, the Arctic is composed of the Arctic Ocean together with the Northern-most territorial reaches of various countries. The arctic area can be defined by various criteria, including by the Northern Polar Circle, and thus within $66.5^{\prime} \mathrm{N}$. Latitude (Jensen, 2007). Approximately 90 percent of the sea is permanently ice-covered while the rest is constituted by the territories of the United States (Alaska), the Russian Federation, Norway, Denmark (Greenland), Canada, as well as many islands under the sovereignty of these countries. The Canadian Arctic is mostly an area of destination for traffic calling at ports there. The Northeast Passage (NEP) is an Arctic Ocean shipping route connecting the Atlantic and Pacific oceans through the archipelago of Canada. NEP traverses from West to East the Barents Sea, Kara Sea, Laptev Sea, the East Siberian Sea, and the Chukchi Sea and it includes the Northern Sea Route (NSR). As to the Russian Arctic, the NSR has become the focus of shipping. It stretches approximately 2,800 kilometers along the Russian Arctic coast from Novaya Zemlya to the Bering Straits.

The discovery of the NSR is one of the most outstanding achievements for the development of North Russia. The length of the NSR from the Kara Strait to the Providence Bay is about 5600 km (History of Northern Sea Route). It became the shortest waterway between the European part of Russia and the Far East. It is a huge advantage compared to shipping routes that are widely used the Suez Canal and the Panama Canal. The distance from SaintPetersburg to Vladivostok via NSR is $14280 \mathrm{~km}$, via the Suez Canal is 23200 $\mathrm{km}$, around of Cape of Good Hope is $29400 \mathrm{~km}$ (History of Northern Sea Route). The NSR may serve as the shortest way between Western Europe and the Asia-Pacific Region. Thus it is possible that it should play an important part in the global process of economic development.

Currently, the Straits of Malacca serves as an important shipping route linking Asian and European trade and connecting the Indian Ocean to the South China Sea and the Pacific Ocean.

Recent political and economic changes in Russia have altered official attitudes about international use of the sea route. The authorities are currently 
encouraging foreign interest in shipping across top Eurasia (Drent, 1993). The use of the Arctic Ocean as a short-cut between Europe and Asia/North America has now been limited. The Arctic is still too icy and treacherous for open-water ships to traverse with any regularity. The NSR is only navigable during the summer months once every seven years or so and too unreliable for commercial shipping. Recent development on Arctic research today is the Arctic is warming much faster roughly twice as much as the global average, $2^{\prime}$ Celsius increase in global temperatures would mean Arctic warming of $3^{\prime}-6^{\prime}$ Celsius. As the ice caps retreats, shipping lanes are opening. Thus it will encourage other trading nations to take into consideration the advantages by using the Arctic shipping routes especially the NSR.

\section{Literature review and methodology}

There were several studies conducted on maritime connectivity globally but not many studies or literature focusing on the Southeast Asian region. The development of maritime connectivity is essential for commercial, economic growth, particularly in the region. Since the end of the Second World War, most Southeast countries had given emphasize on domestic development like building infrastructure such as roads, rails and telecommunications (Thomas \& Chia, 1998). At the same time, the region needs to be connected in terms of maritime transport to enable import and export activities that will promote economic growth. Since almost 90 percent of cargoes are transporting through the sea, the Straits of Malacca remain important an international route for merchant shipping and international trade (Hanizah Idris \& Hanafi Hussin, 2018; Khalid, 2012; United Nations Conference on Trade and Development [UNCTAD], 2017). As the volume of seaborne trade grows, so as the increase of traffics at the Straits of Malacca that amounted to 90,000 vessels plying the straits annually (Hanizah Idris, 2018). On the other side, the increase in cargos transported between the Far East and Europe using the navigation via Suez Canal had created a congestion problem and the total time (waiting time + canal crossing) spends at this area is longer compared to the past 10-15 years (Abdul, Abdul, \& Rasdi, 2016).

This had brought to the discussion on the use of NSR in the Artic Region as an alternative route for the Straits of Malacca due to the global warming that could potentially enable merchant shipping to be carried out between northern East Asia and northern Europe all year long. This could have repercussion on trade related to ports in the East Asian region and could well impact the interests of Malaysian ports and shipping companies (Khalid, 
2012). In 2013, Singapore had shown its interest in the Arctic shipping by becoming an active member of Artic Council together with China, Korea, and Japan. Consequently, the NSR is identified as the most promising Arctic seaway with a considerable potential to shorten sailing distances from Europe to Asia and vice versa (Toccheto, Tancredi, Araujo, \& Noronha, 2014). In order to strengthen the maritime economy, decision strategies are crucial for port development and maritime activities in the Southeast Asian region.

The methodology used in carrying out this study is based on report analysis, which provides empirical evidence related to maritime development and maritime connectivity in general. Data collections were extracted from Annual Reports, bulletins, and official reports from Maritime Institute of Malaysia (MIMA), ASEAN Master Plans on ASEAN Connectivity, United Nation Conference on Trade and Development (UNCTAD), Asian Development Bank (ADB), and the World Bank. Information is gathered through these reports since there are not many kinds of literature published on the maritime connectivity of the Southeast Asian Region and Northern Sea Route.

\section{Maritime Connectivity in the Southeast Asian Region}

The importance of maritime connectivity is essential to condition for economic growth. Transports links do not only provide physical excess to resources but also enable producers to take advantages of opportunities in the domestic and foreign market, leading to an economy of scale and specialization (Trace, Frielink, \& Hew, 2009). In a globalized world, efficient connections between the Southeast region and international markets are essential. Improved connectivity at a regional level widens the potential market available to local producers, providing opportunities to specialize in agricultural or industrial production. Since the bulk of the Southeast Asia region's international trade is carried by sea, access to high-quality international shipping services is of paramount importance (Trace et al., 2009).

Southeast Asia is an archipelagic region, consisting of thousands of islands poorly connected that have strategic value for many countries outside the region (Toccheto et al., 2014). It is a region with a total population of approximately 600 million and the fact that Indonesia's population is over 200 million is very well known (Osborne, 2013). There are important straits located in the region like the Straits of Malacca, the Straits of Singapore and the Straits of Sunda which are significant for international trade (Figure 1). The Straits of Malacca being the second important international sea route is a narrow 
passage with a total length of the waterway between the extremities is 500 nautical miles or $800 \mathrm{~km}$ long and the width of the straits a varies, being 200 nautical miles at its widest point and narrowing funnel-like to the southern extremity of only 11 nautical miles (Nordin Hussin, 2008). One of the main issues of the region is the depth of the ports and straits that can prevent bigger ships from passing the straits.

Historically, maritime connectivity in the region started way back during the glorious maritime kingdoms like Srivijaya, Majapahit, Malacca, and Temasek (Singapore). These were great seaports and foci of communications which developed in response to the increasing volume of seaborne trade in the Malay waters (Nordin Hussin, 2008). The region was connected with the Indian Ocean and the Far East (China and Japan) by the South China Sea and passed through the Straits of Malacca to the West and the Middle East (Hanizah Idris, Tan, \& Mohammad Raduan Mohd. Ariff, 2008). The importance of the Strait of Malacca in global trade continued with the rise of Malacca Sultanate in the fifteenth century, followed by the rise of Singapore as a modern emporium in the nineteenth century under the colonial era. Singapore was founded by the British in 1819 although it has been discovered earlier in the fourteenth century and was known as Temasek.

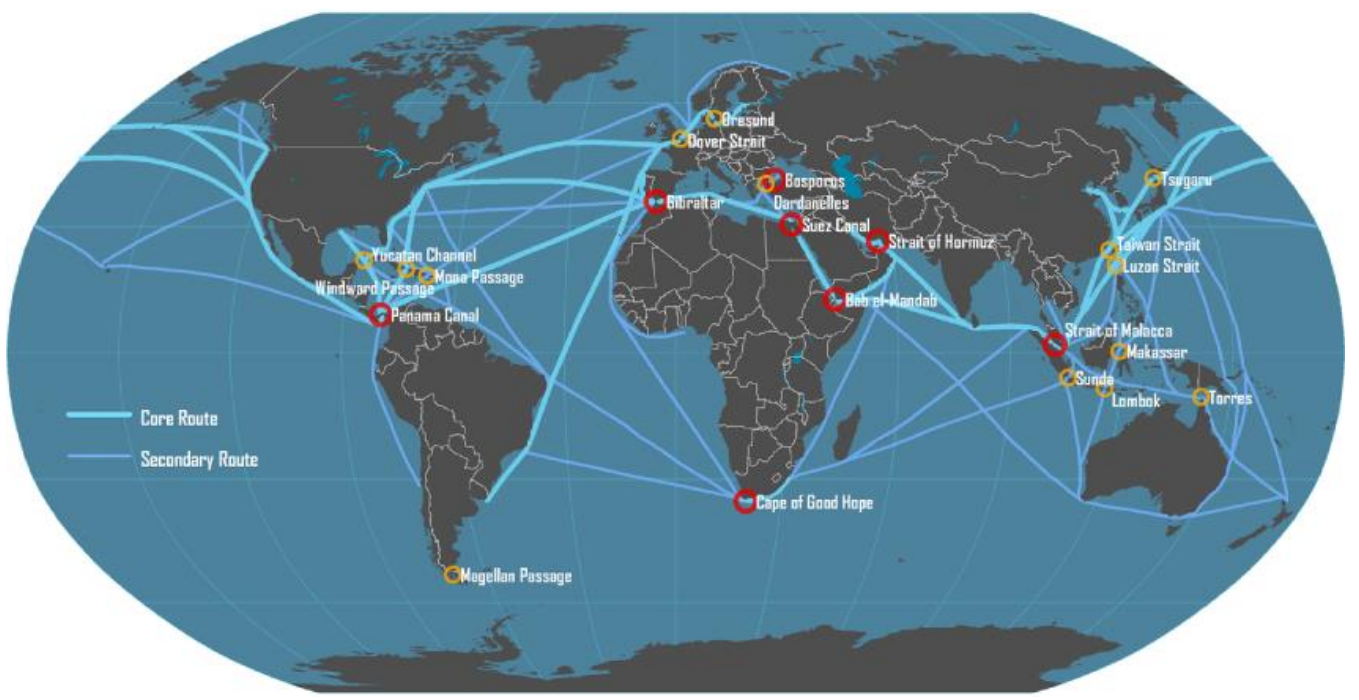

Figure 1: Maritime shipping route including the Straits of Malacca Source: Urban Gallery (n.d.).

During the British Era, Singapore was developed as a regional port controlling the East-West trade via the Straits of Malacca. The British had succeeded in making Singapore as the center of communications at that time 
and became the center of British administration in the region (Hanizah Idris et al., 2008). Many foreign merchants have found it more economical and reliable to purchase their goods from ports along the Straits. Apart from being the main ports of transshipment, these entreports were also major export centres for local products from the Malay Archipelago (Nordin Hussin, 2008).

Today, the Straits of Singapore became among the world's busiest commercial routes, being considered the location of the second largest port in the world, the port of Singapore. The volume of shipping is three times that navigate through the Panama Canal and double that uses the Suez Canal. Nearly one-third of the 61 percent of total global petroleum and other liquids that moved on maritime routes transited the Straits of Malacca in 2015. More than 94,000 vessels pass through the Straits every year carrying one-fourth of the world's traded goods, including approximately 15.2 million barrels of oil per day in 2015 (Wijeratne \& Clayton, 2018).

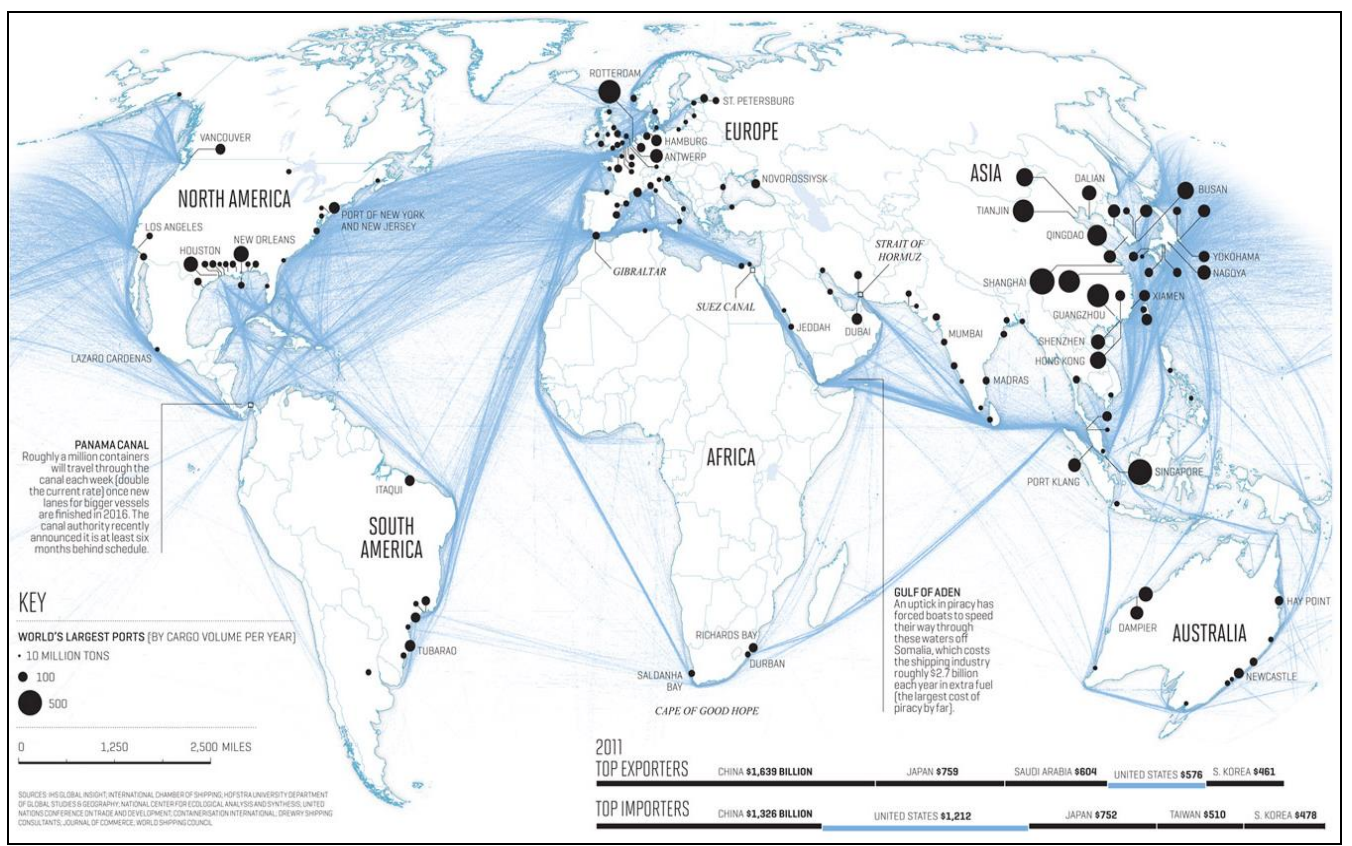

Figure 2: World ports concentration which focuses on Asia

Source: "Mapping supply chains in the global economy" (2014).

Figure 2 shows the world ports concentrated which focus in Asia with developing economies like China, Korea, Japan, Singapore, and Malaysia. While Port Klang and the port of Tanjung Pelepas (PTP) which are located at the Straits of Malacca were among the top 20 container ports in the world (United Nations Conference on Trade and Development [UNCTAD], 2017), the 
total cargo handling by these ports had reached almost 50 million twenty equivalent units (TEU) per year, where almost 30 million TEU are handled by Singapore Port.

Table 1 shows Southeast Asian major ports namely the Port of Singapore, Port Klang and PTP and other major ports in the world with the port of Shanghai being the highest in terms of container handling followed by Singapore. The total throughput handling by the top 20 world container ports also shows an increase from 254543912 million TEU in 2014 to 274364468 million TEU in 2016 despite the slowing down in the global economy due to weaker world economic growth.

Currently, the Straits of Malacca and the Straits of Singapore had to receive an average of 140,000 vessels annually. The major ports along the straits namely Singapore Port, Penang Port, Port Klang, PTP, and Belawan port continued to play a vital role in international trade and shipping in the region. Figure 3 shows the crude oil trade flows from major ports in East Asia including China, Hong Kong, Korea, and Japan to selected ports located in the Southeast Asian region namely Singapore and Malaysia, by pass Indonesia and the Philippines.

In terms of maritime connectivity in the region, many areas of mainland Southeast Asia are still poorly connected like Cambodia, Laos, Myanmar, and Vietnam, known as CLMV countries. Even, the maritime countries like the Philippines and Indonesia are still struggling in providing port and shipping infrastructure and facilities. There are facing problems in developing infrastructure and connectivity including rails, roads and also maritime connectivity. Therefore, improving physical maritime connectivity with those countries is essential to achieve greater integration within the region economically and socially. Most of the gateway ports of Southeast Asia are already "fairly full" which means the investments in capacity expansions would have to be made in order to meet the growth in trade expected from the deeper economic integration of the ASEAN Member States among themselves with the rest of the world (Master plan on ASEAN connectivity, 2011).

Maritime transport is the most important mode of transportation in terms of the traffic volume in international trade. Southeast Asian region is blessed with a geographic deposition favourable to maritime trade. The access to major sea lanes provides connectivity to the global markets. Singapore port and Malaysian ports, Port Klang and port of Tanjung Pelepas remain under top 20 world container ports, whereas other ports in Southeast Asian countries like Thailand, Indonesia, Vietnam, and the Philippines were ranked from 22 to 35 respectively. 
Table 1: Top 20 world container ports, 2014-2016 million (TEU)

\begin{tabular}{|l|c|c|c|}
\hline Ports & $\mathbf{2 0 1 4}$ & $\mathbf{2 0 1 5}$ & $\mathbf{2 0 1 6}$ \\
\hline Shanghai & 35290000 & 36540000 & 37135000 \\
\hline Singapore & 33869000 & 30922000 & 30930000 \\
\hline Shenzen & 20040000 & 24200000 & 23980000 \\
\hline $\begin{array}{l}\text { Ningbo \& } \\
\text { Zhoushan }\end{array}$ & 19450000 & 20630000 & 21565000 \\
\hline Hong Kong & 22200000 & 20100000 & 19580000 \\
\hline Busan & 18683000 & 19467000 & 19378000 \\
\hline Guangzhou & 16610000 & 17590000 & 18859000 \\
\hline Qingdao & 16580000 & 17430000 & 18050000 \\
\hline Dubai & 15200000 & 15590000 & 14772000 \\
\hline Rotterdam & 12298000 & 12235000 & 12385000 \\
\hline Tianjin & 14060000 & 14110000 & 14523000 \\
\hline Kaohsiung & 10593000 & 10260000 & 10460000 \\
\hline Port Klang & 10946000 & 11887000 & 13167000 \\
\hline Hamburg & 9720000 & 8821000 & 8900000 \\
\hline Antwerp & 8978000 & 9654000 & 10037000 \\
\hline Los Angeles & 8340000 & 8160000 & 8857000 \\
\hline Tanjung Pelepas & 8500000 & 9130000 & 8029000 \\
\hline Xiamen & 8572000 & 9180000 & 9614000 \\
\hline Dalian & 10130000 & 9450000 & 9584000 \\
\hline Long Beach & 6818000 & 7190000 & 6775000 \\
\hline $\begin{array}{l}\text { Total throughput } \\
\text { of 20 container } \\
\text { port }\end{array}$ & $\mathbf{2 5 4 5 4 3 9 1 2}$ & $\mathbf{2 7 4 3 6 4 4 6 8}$ & $\mathbf{2 7 4 3 6 4 4 6 8}$ \\
\hline & & & \\
\hline
\end{tabular}

Sources: United Nations Conference on Trade and Development (UNCTAD) (2016, p. 69); United Nations Conference on Trade and Development (UNCTAD) (2017. p. 65).

Singapore and Malaysia are the countries with the best state-of-the-art port infrastructure of the region, but even so, they need investments in order to achieve greater capacity, as they are big hubs (Toccheto et al., 2014). According to Asia Development Bank, from 2010 to 2020, Asia will need to invest around U\$8 trillion in overall national infrastructure, and in addition, about U\$290 billion in specific regional infrastructure projects (Trace et al., 2009). The Master Plan on ASEAN Connectivity (2011) identifies public-private partnerships (PPPs) as a way to coordinate government and private sector actions in developing infrastructure projects of the region. 


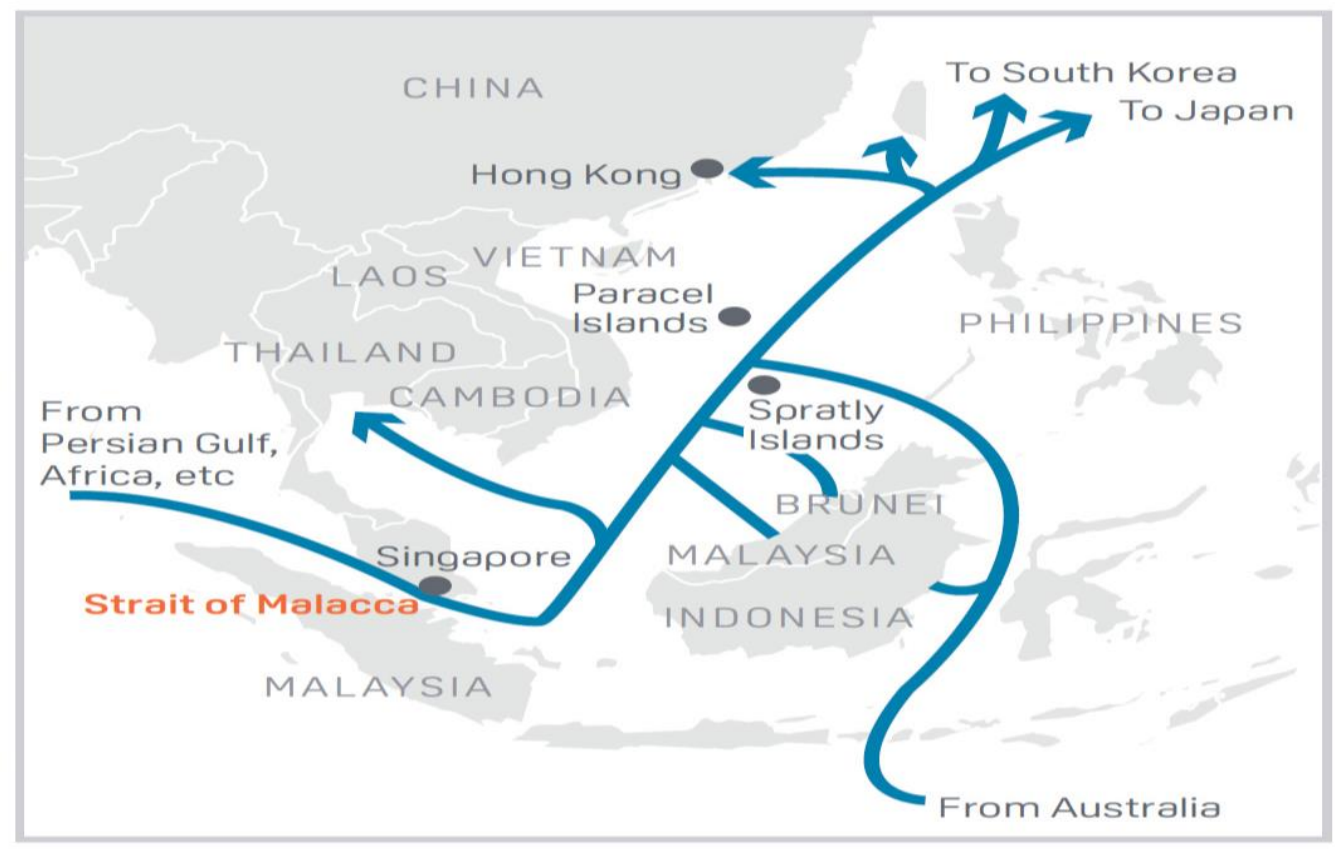

Source: EIA

Figure 3: South China Sea Oil, LNG trade routes

Source: Quoted from “The South China Sea is an important world energy trade route" (2013).

For the past ten years, Malaysian ports had aggressively improved their connectivity by providing a more conducive environment for global supply chain and by offering integrated inter-modal services on a "door-todoor" basis. Malaysian premier ports Port Klang and PTP involved in massive expansion including the building of new berths and containers yards that subsequently raises their total annual handling to 21 million TEUs in 2016 . The efficient port services at PTP, have led major container liner companies such as Maersk and Evergreen to introduce more service calls at the port (Hanizah Idris, 2018).

In terms of international shipping growth and development, although the international seaborne trade is still influenced by the Great Recession (2009), there are other developments that can stimulate the seaborne trade especially for developing countries in the Asian region. They include infrastructure development initiatives, developments in trade policy and liberalization, population growth and urbanization and the growing use of ecommerce (United Nations Conference on Trade and Development [UNCTAD), 2016). In 2015, a number of infrastructure development and 
expansion were announced, launched or completed, to improving connectivity, enhancing access to suppliers and consumers and enabling trade and regional integration (United Nations Conference on Trade and Development [UNCTAD], 2016). Such initiatives included the construction, expansion and improvement of logistics infrastructure and physical assets such as Panama Canal and Suez Canal, as well as One Belt, One Road initiative in China and the joint Japan-Asian Development Bank Partnership for Quality infrastructure (United Nations Conference on Trade and Development [UNCTAD), 2016); Hanizah Idris, 2018).

Launched in 2013, the One Belt, One Road initiative aims to establish new trading routes, links and business opportunities by further connecting China, Asia, Europe, Africa and countries with economies in transitions along five routes. Meanwhile, the Japan International Cooperation Agency (JICA) has a project for a Maritime Corridor in Southeast Asia, comprising Malaysia, Singapore, Indonesia, Brunei, and the Philippines. The initiative is part of a partnership between ASEAN and Japan for connectivity in Southeast Asia, for which Japan is contributing with ideas of connectivity infrastructure projects (Toccheto et al., 2014).

\section{The Development at the Northern Sea Route of the Arctic Region}

The Northeast Passage (NEP) is a historic term for the transit route north of Russia linking together the Northern Atlantic and Northern Pacific Oceans. It is a somewhat abstract term without strictly defined borders or end-points. On the other hand, NSR which is the term used by Russia today is clearly defined entity and had been used for important waterway since the 1930s in support of the industrial development of its Arctic resources (Ragner, 2000). Navigation in Arctic waters is unique compare to all ship operations (Figure 4).

Sea ice and water depths are two main impediments to navigation. The climactic volatility, thick sea-ice, and other hazardous conditions make it inhospitable and largely inaccessible for the majority of the year. The ship is the most suitable transportation despite the limited shipping season and severe environmental condition at the Arctic region. As it is a dangerous region with many obstacles, all vessels making the transit must have varying levels of ice-certified hulls, proper equipment, and adequate training.

The actual route used depends on ice conditions. Extra costs will incur for a special ship like ice-strengthened vessels, insurance and maintenance, and icebreaking and pilotage not to mention port development and related 
infrastructure in the area. Annual Cargo traffic in the NSR is relatively small as to compare with other routes.

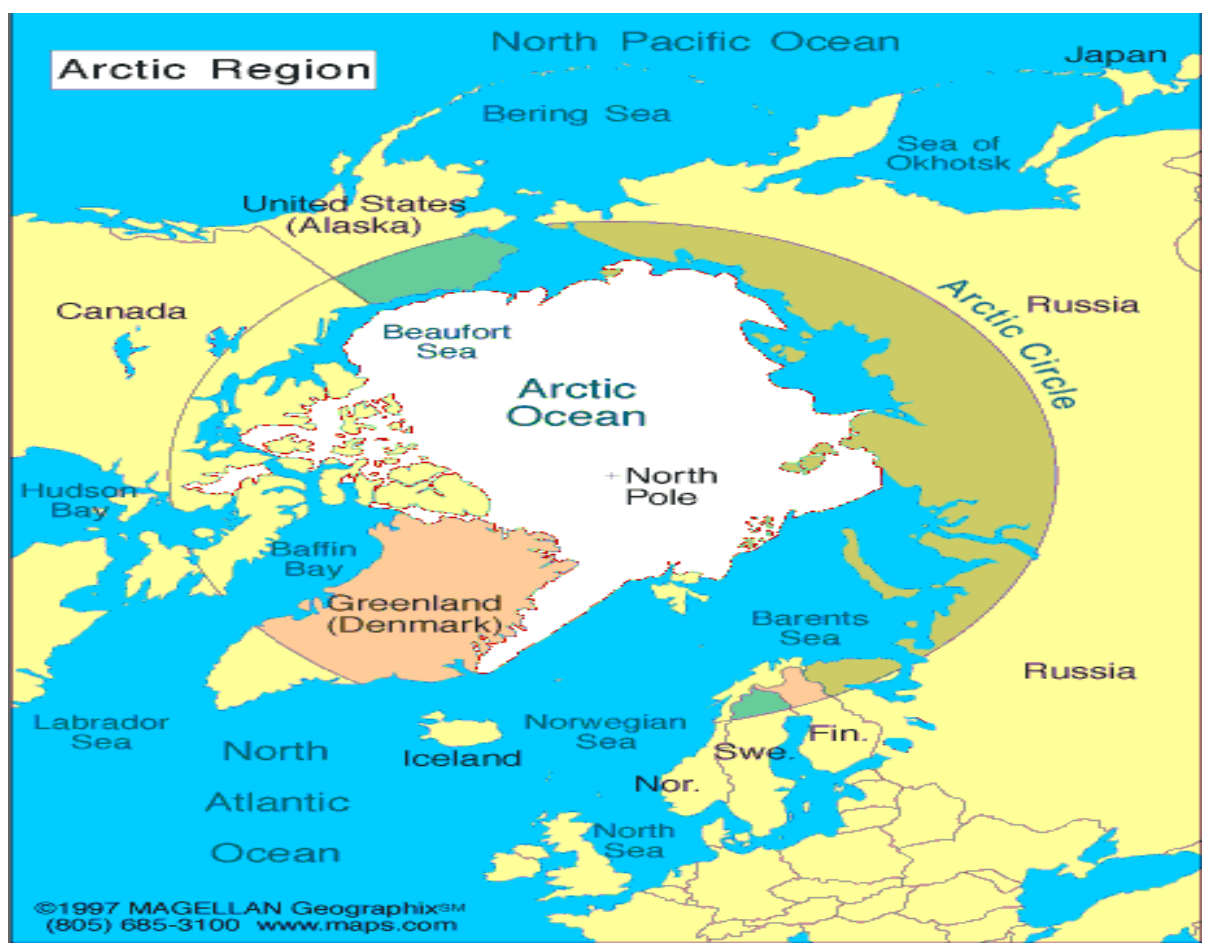

Figure 4: Arctic Region

(Source: Pinterest (n.d.).

Optimistic forecasts predict that the volume of world trade will double over the next two decades and visionaries are thinking of increasing the use of the Arctic route between Europe and Asia and capturing new traffic between Europe and North America. Between late June and mid-November parts of the route are ice-free, and conditions improve progressively between June and September. The whole system is open for a period in the summer, but all sections are not necessarily open simultaneously (Drent, 1993). Historically, Arctic navigation was confined to supplying local communities during the summer season. Many hampered human efforts to travel within the region and take advantage of its resources.

While the entire route is affected by ice for much of the year, in the summer there is melting due to the combined effects of milder temperatures and the influx of warmer water (Drent, 1993). The motivation to navigate the Northern passage was initially economic. As early as sixteenth-century explorers and traders started several voyages in search of the Northeast 
Passage and by the seventeenth century, traders had established a continuous sea route from Arkhangelsk to the Yamal Peninsula, where they portaged to the Gulf of Ob. This route was known as the Mangazeya seaway, after its eastern terminus, the trade depot of Mangazeya was an early precursor to the Northern Sea Route. Later expeditions to explore the North East Passage took place in the 1760s, 1785-95, the 1820s and 1830s. The expedition managed to map much of the western part of the NEP but was all either wrecked or forced to return by the difficult ice conditions.

The possibility of navigation of the whole length of the passage was proved by the mid-nineteenth century. In 1878 Finish-Swedish explore Nordenskiold made the first complete passage of the North East Passage from west to east, in the Vega expedition lead by Lieutenant Louis Palander of the Swedish Royal Navy. Commercial exploitation of the section of the route started with the Kara expeditions, exporting Siberian agricultural produce via the Kara Sea where of 122 convoys between 1877 and 1919 only 75 succeeded transporting as little as 55 tons of cargo. From 1911 the Kolyma steamboats ran from Vladivostok to the Kolyma once a year.

The relevance of NEP as an international transit waterway further diminished after the Russian Revolution in 1917. Since then, access to the Russian Arctic became restricted for non-Soviet vessels. The expedition of Otto Schmid on steam ice breaker "Alexandder Sibiryakov" in 1932 was the starting point for opening regular traffic along the Northern Sea Route. The steamship with a displacement of 3200 tons put to sea from Arkhangelesk on the 28 July 1932 and reached port Dickson on the 3 of August 1932. Successful expedition of Otto Schmidt proved the possibility of active development in the Arctic. GLAVSEVMORPUT (Northern Sea Route General Office) was established to put the idea of Arctic development to practice (Drent, 1993). The Soviet Union was the first and the only country actively using drift-ice research stations.

The idea came from Vladimir Vize, a researcher of Scientific Research Institute of the Arctic and Antarctic and in 1937 the team of the first drift-ice research station arrived on site. Before the Great Patriotic War, the ports of Dickson, Dudinka, Tiksi, Pevek, and Provideniya were under construction. To the Soviet Union, the NSR also had a military role. During the war apart from supply of the Arctic construction sites and research stations, it is necessary to ensure supply of garrisons and warships and to receive goods delivered from the USA and Canada. NSR activity was at its peak in 1987 when 6.6 million tons of cargo was transported on the route. In this year the Soviet President Gorbachev for the first time proposed to open up the NSR to non-Soviet 
vessels, an initiative which was followed-up by the formal opening of the NSR to foreign vessels on 1 July 1991 (Ragner, 2000).

\section{The potential for Commercial Shipping at Northern Sea Route}

On the other hand, the positive development of the NSR in terms of shipping traffic had created new implications on trading nations such as China, Japan, South Korea, and Singapore. In 2013, Japan, Singapore, and South Korea also joined as a permanent observer at the Arctic Council. NSR has the potential to drastically reduce sailing distances, costs and times between northern Europe and East Asia. Initial estimates suggest the current 40 days, the 22,000kilometer voyage from northern Europe to East Asia (routed through the Suez Canal and Straits of Malacca) could be transformed into a 30-day, 15,000kilometer trip via the NSR.

The NSR is an integral part of the economy, and it is vital for the regions of the Extreme North and the Far East. The most outstanding voyages along the Northern Sea Route in the 1940-1970s, included transportation of manufactured products and foodstuffs, delivery warships, and navigations of fishing boats. It ensures the supply of remote areas with fuel, foodstuffs and essential goods and supply of the continent with natural resources. Shipping in the Arctic area is not only affected by social and economic developments, but it is also very much determined by sea-ice conditions. The biggest challenges are ice from October to June, the Arctic Ocean remains largely icelocked, making surface navigation impossible for all vessels, except icebreakers. Arctic shipping can be divided into many categories such as commercial vessels including tankers and fishing vessels, vessels for recreations and tourism, scientific research vessels, icebreakers for re-supply and vessels engaged in offshore exploration.

In 1978, the first all-year route was initiated between the Yenisey port of Dudinka and Murmansk, transporting metals and ores from the Norilsk Industrial complex, with ice breaker escort during the winter season. Since the 1970s the NSR has also been used as an important supply line for the development of Russia's northern oil and gas industry. NSR route activity was at its peak in 1987, but as the Soviet system started to crumble, it soon becomes difficult for the state to uphold the high level of subsidies that was required to maintain most activities in the Arctic, and NSR cargo volumes diminished (Figure 6). After the Soviet Union's disintegration, volumes gradually fell, before having come to the stable level of 1.5-2.5 million tons per year since 1996 (Drent, 1993). 
Volumes are expected to keep rising. Since 2000, small tankers have transported gradually increasing volumes of oil from the new Varander terminal on the Pechora coast, with most shipment going directly to Western Europe. In addition, since 2002 a new export route with oil shipments from several White Sea ports to Murmansk and Western Europe has developed, with oil shipped to the ports by rail. The export of metals has added to the volumes of sea transportation on the NSR, and forecasts indicate that future tanker trade in Northwestern Russia will increase substantially over the next years, take into consideration safe shipping conditions, better communications as well as improve navigational charts (Figure 5).

In 2013, traffic in NSR connected ports as far as west as Ammassalik (Greenland) and as far as east as Vancouver, Canada. In total, vessels travelling along the NSR called at 47 ports in 14 countries. The port of Murmansk, Russia represented the key hub for shipping in NSR with 27 vessels, carrying 492,000 tons of cargo. The port of Pevek, Russia located near the eastern entrance of the

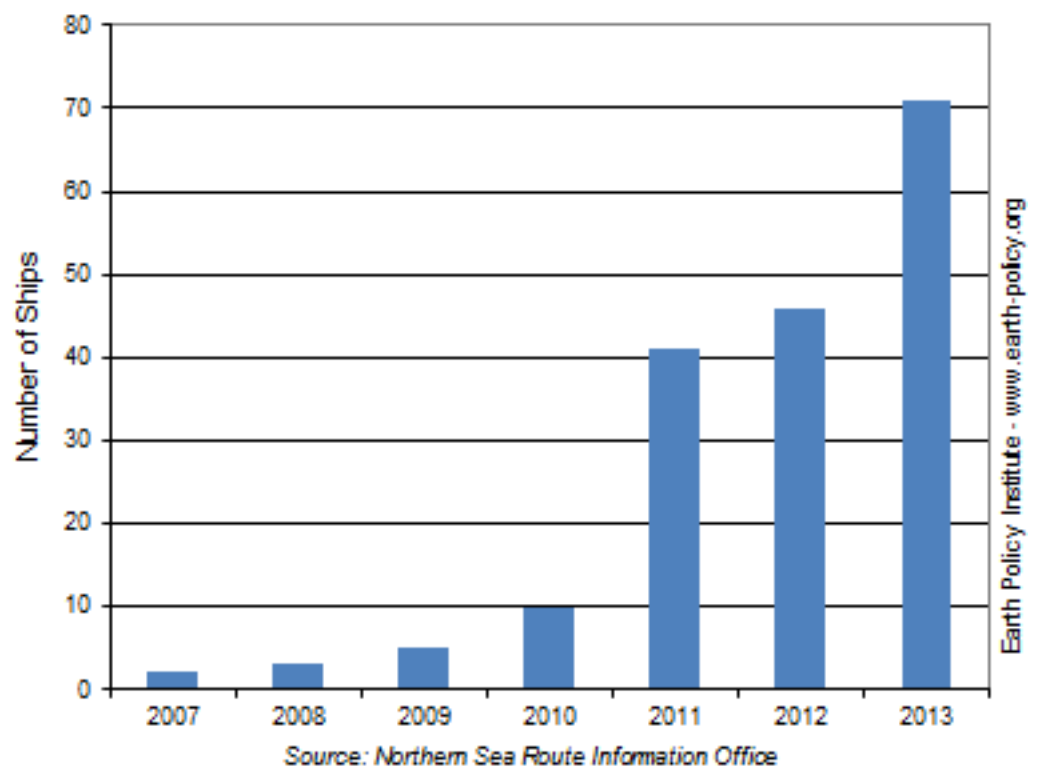

Figure 5: Shipping at Arctic Northern Sea Route 2007-2013 Source: Northern Sea Route Information Office. (n.d.).

NSR counted 18 vessels with a total of 311,000 tons of cargo. Other important ports were Rotterdam (Netherlands), Mongstad and Hemmerfest (Norway) in Europe accounting for six ships and 421,000 tons. About 286,000 
tons of cargo, representing 21 percent of traffic departed from or arrived in Chinese ports. China Ocean Shipping Company (COSCO Shipping) continues to be a consistent player on the NSR route in recent years (Figures 6, 7 and 8).

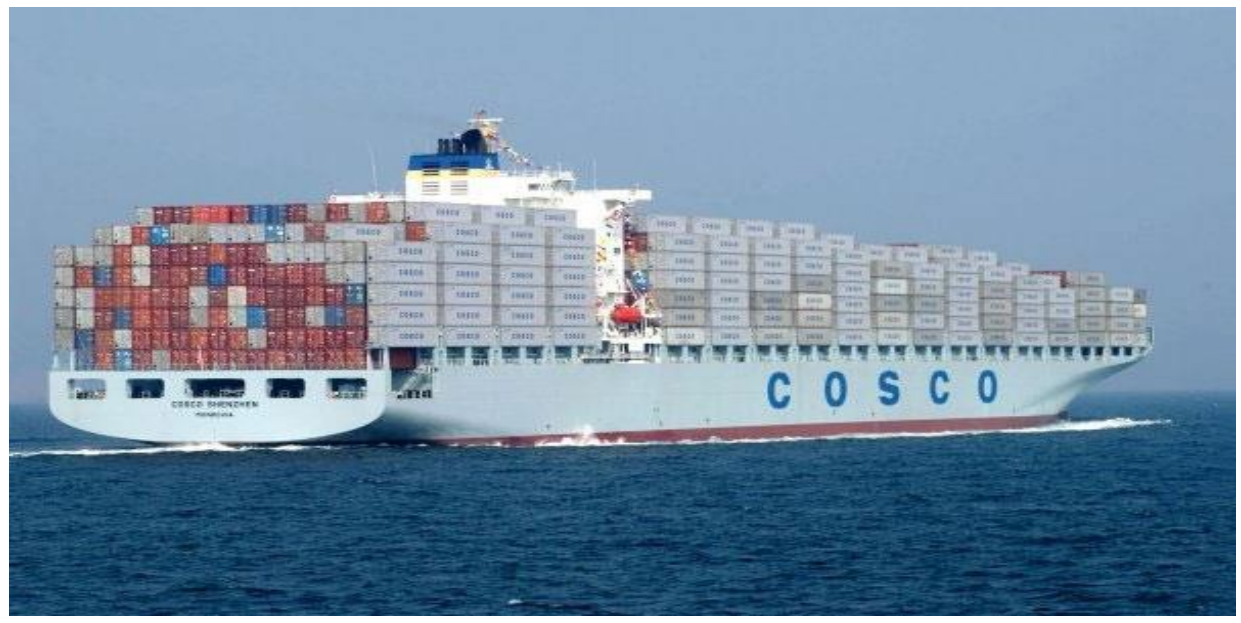

Figure 6: Chinese ship "COSCO" passing through the Northern Sea Route Source: Pettersen (2015).

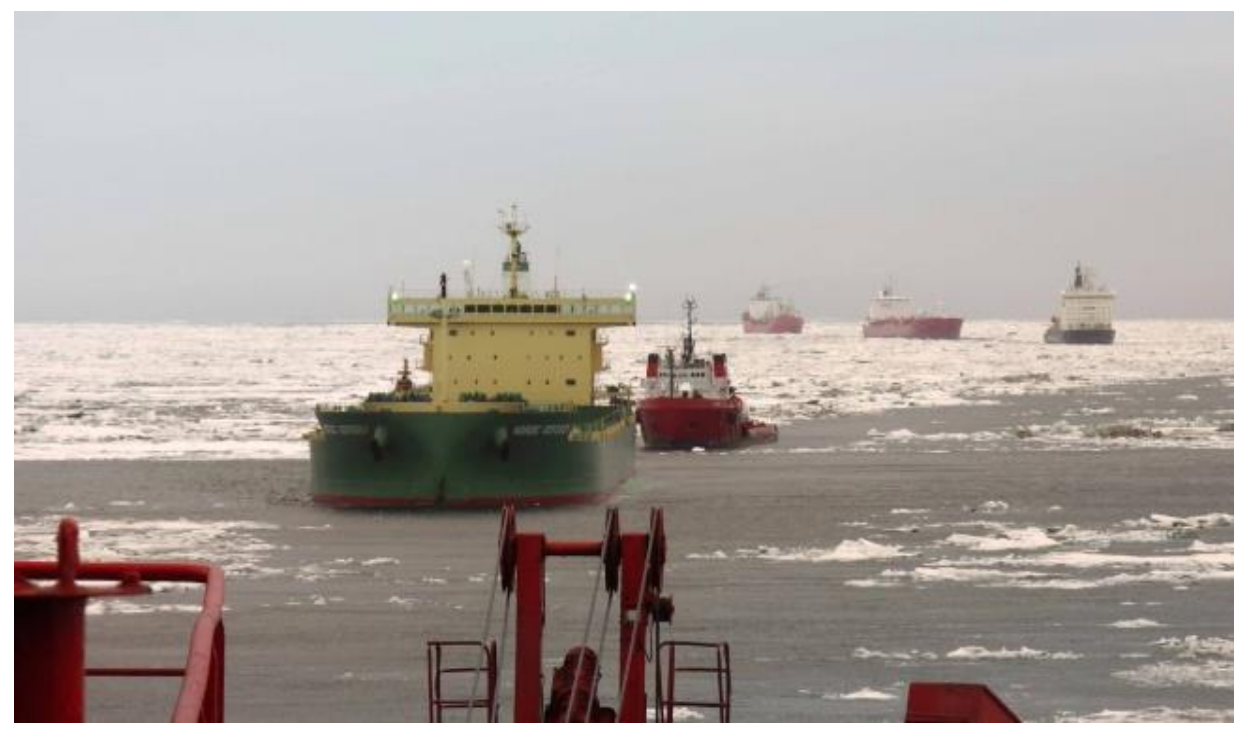

Figure 7: Vessels Passing Through the Northern Sea Route Source: Pettersen (2015). 


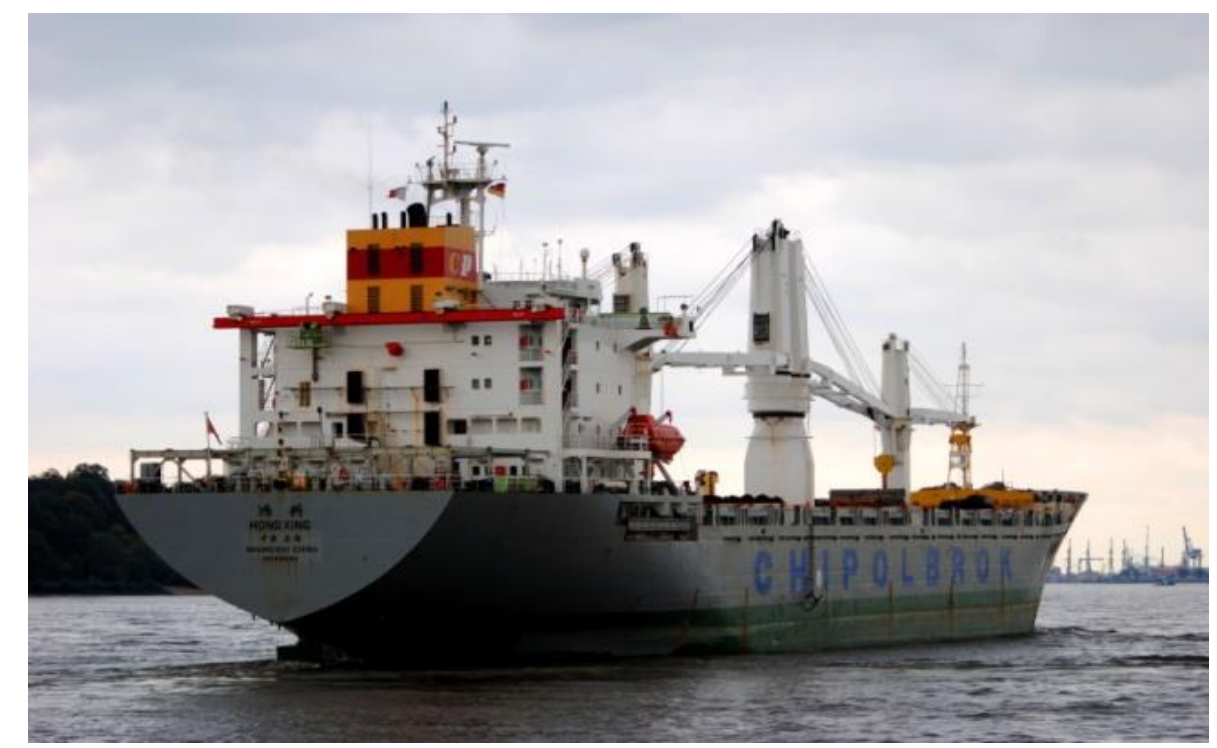

Figure 8: Chinese merchant ship "Hong Xing" to sail the Northern Sea Route from Asia to Europe

Source: Pettersen (2015).

It had its first NSR voyage in 2013, followed by a roundtrip transit in 2015. In 2015 a total of 5.4 million tons of goods and project cargo were transported on the NSR, up from 4.0 million tons in 2014 and 3.9 million tons in 2013. The NSR Administration received a total of 715 applications for sailings on the NSR in 2015, thereof 126 from foreign flag ships (Gunnarsson , 2016). The year 2016 saw two transits by COSCO ships, and plans are in place for more. In 2017, shipping traffic at NSR experienced significant growth compared to the year 2016.

\section{The future challenges and constraints of NSR route}

Newcomers to the NSR need to have a firm understanding of the challenges and requirements. The main physical constraints to NSR shipping are the shallow seas and straits along most parts of the route, and above the difficult ice conditions. There are signs that ice-conditions are becoming slowly lighter, possibly due to climate change (Ragner, 2000). With the record low Arctic ice coverage in 2007, navigation via formerly impenetrable NSR became a viable option and an apparent maritime fast lane (Yu \& James, 2017). The NSR opened to foreign-flagged cargo ships in 2009 with two German vessels.

Transporting heavy equipment from the Far East to Novy Port, located at the mouth of the Ob River on the Yamal Peninsula in Russia's Yamalo- 
Nenets Autonomous Region. The transit cargo volume grew from 111,000 tons in 2010 to 1.356 million tons in 2013, with a total of 71 transits. Activity during this period allowed the industry to evaluate future possibilities for NSR transit shipping carried out through some exploratory or demonstration voyages with large crude oil tankers and LNG carriers.

The distinct feature of the Russian Arctic is the shallowness of its sea which creates at least three major problems for shipping, namely:

(i). The shallowness of the straits through the New Siberian Islands seriously limits the draft and size of ships that can use the whole NSR on a regular basis.

(ii). The shallowness of the coastal areas forces deep-draft ships to choose routes far from the coast. This creates additional problems for larger ships since ice conditions often are better close to the coast, where small islands and other local features may provide shelter from drifting ice.

(iii). The shallowness of the coastal areas and the Arctic ports seriously limit the size of ships that can call at the Russian Arctic. Another serious consequence is the inability of larger ships to seek shelter and repair in emergencies (Figures 9 \& 10).

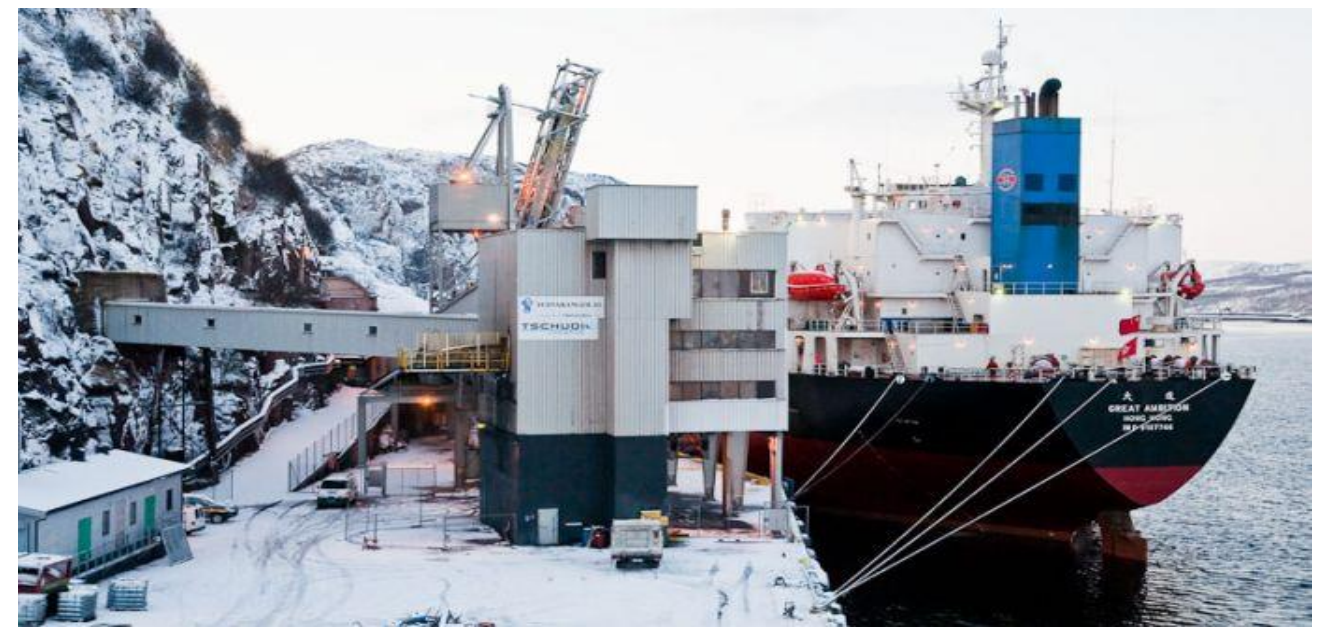

Figure 9: Port infrastructure in the Arctic Region

Source: Bing images feed. (n.d.). 


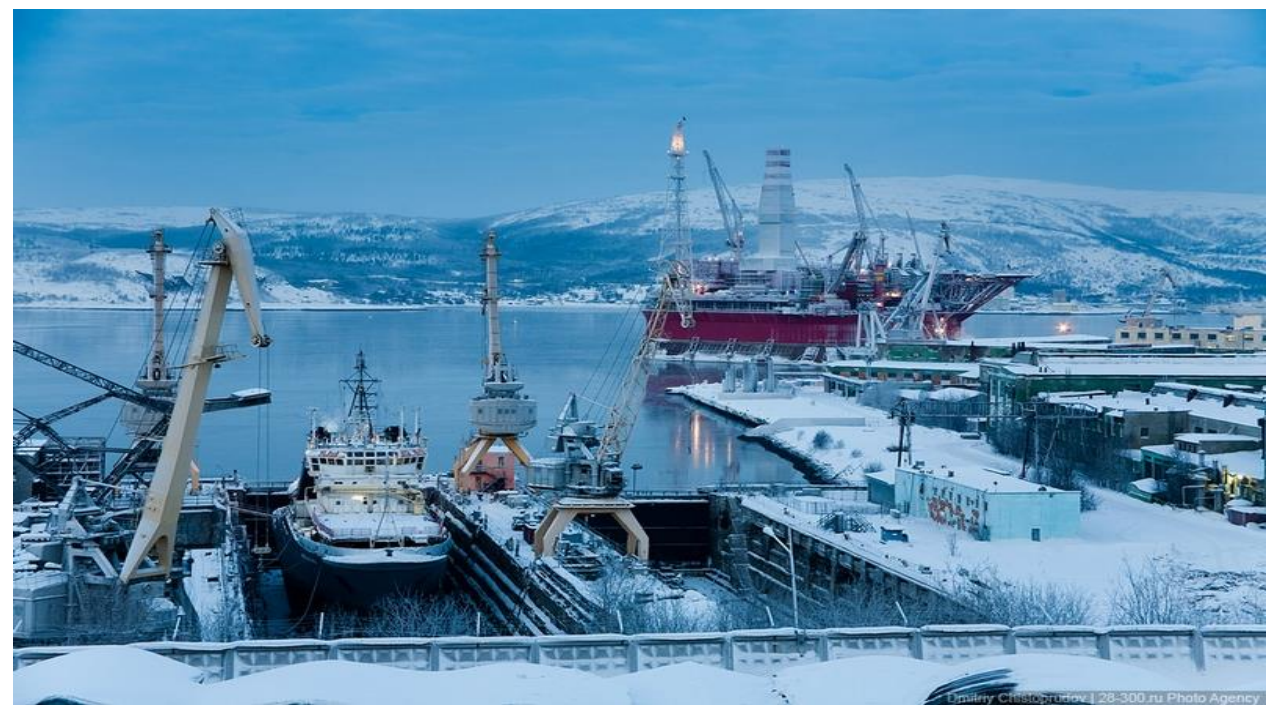

Figure 10: Port of Murmansk, the great Arctic port

Source: Bing images feed. (n.d.).

In terms of climate change, although there is a concern of extremely difficult ice-conditions on the NSR, a growing number of reliable research reports indicate that the polar ice cap is shrinking at an unprecedented rate, and some research report indicates that the pace is dramatic (Claes Lykee Ragner). If these trends continue, it is projected the entire Arctic Ocean will become ice-free during summer before the end of this century. This would change the conditions for prospects of shipping on the NSR for commercial shipping in the future fundamentally.

The Russian government recently released Russia's Integrated Development Plan for the NSR 2015-2030. The plan stresses the importance of providing safer and more reliable navigation on the NSR for maritime export of Russian natural resource materials but also the strategic importance of NSR for Russian national security. The plan is also to increase international transit cargo transportation on NSR in partnership with Asian countries and in particular with China.

\section{Conclusion}

Southeast Asian region is in need of continuous investments to improve maritime connectivity including land transport and supply-chain infrastructure to support port and shipping developments. At the moment, the region as well the international trade and shipping are very much dependence 
on the Straits of Malacca which is the chokepoints in the SLOCs system. Whether the NSR will become an alternative route for international seaborne trade in the future is still uncertain. Despite the obstacles and challenges in terms of developing shipping technology and port infrastructure, it is rather ambitious to develop maritime connectivity between the Southeast Asia region and the Arctic region through the NSR. Nevertheless, Singapore and the East Asian countries like Japan, Korea, and China had shown their interest in using the route for exporting crude oil. China's interest in Arctic shipping is taken an important factor in the development of the NSR. Consequently, the NSR is identified as the most promising Arctic seaway with a considerable potential to shorten sailing distances from Europe to Asia and larger extend vice versa.

According to the Federal Agency for Sea and Inland Transport, the cargo traffic along the NSR will reach 44 million metric tons in 2020 and 70 million metric tons in 2030 (The Arctic, 2018). Therefore, the Arctic is no longer unreceptive to regular shipping voyages, and analyzing the trends over the next few years will no doubt indicate strong leaders in the field to take advantage of the economic benefits that lie in the NSR. Taking into consideration other development like climate change has provided an opportunity for shipping routes and port developments to improve maritime connectivity.

\section{Acknowledgement}

The authors would like to thank and acknowledge and acknowledge the financial support provided by University of Malaya under the Research Clusters Equitable Society Research Cluster (ESRC) for the research grant RP01A-13SBS and RUGrant Faculty Program 2018-2019 for the research grant GPF007J-2018.

\section{References}

Abdul, N. S. F., Abdul, S., \& Rasdi, R. (2016). Decision strategies for boosting maritime economy in Malaysia the opening of Northern Sea Route. Journal of Maritime Research, XIII(III), 13-20. Retrieved from https://www.jmr.unican.es

Bing images feed. (n.d.). Retrieved from https://www.bing.com/images/

Drent, J. (1993). Commercial Shipping on the Northern Sea Route. The Northern Mariner/Le Marin du nord, III(2), 1-17. 
Gunnarsson, B. (2016, 18 February). Future development of the Northern Sea Route. Retrieved from http://mediakit.maritimeexecutive.com/author/marex

Hanizah Idris. (2018, 7 August). Malaysia's development depends on international and domestic support for maritime connectivity. Asia Pacific Bulletin, 436. Washington D.C: East-West Center. Retrieved from http://www.eastwestcenter.org/print/3676

Hanizah Idris, \& Hanafi Hussin. (2018). Improving intra-ASEAN connectivity and inland waterways network for further integration of the coastal shipping and tourism sector developments. JATI-Journal of Southeast Asian Studies, 23(1), 75-101. Retrieved from http://jati.um.edu.my/index.php/jati/article/view/12188

Hanizah Idris, Tan, W. H., \& Mohammad Raduan Mohd. Ariff. (Eds). (2008). Maritime social and economic developments in Southeast Asia. Monographs Series. Kuala Lumpur: Institute of Ocean and Earth Science, University of Malaya.

Khalid, N. (2012). Staying the course: Swimming with the tide of changes and developments in the shipping industry. MIMA Bulletin, 19(3), 4-12.

Jensen, O. (2007). The IMO guidelines for ships operating in Arctic ice-covered waters: From voluntary to mandatory tool for navigation safety and environmental protection? Lysaker: Fridtjof Nansen Institute.

Leinbach, T.H. and Chia Lin Sien. (1989). South-East Asian Transport: Issues in Development. Singapore: Oxford University Press.

Mapping supply chains in the global economy. (2014, 18 October). Supply Chain 24/7's website. Retrieved from http://www.supply chain247.com/article/mapping_supply_chains_in_the_global_economy

Master plan on ASEAN connectivity. (2011). Jakarta: The ASEAN Secretariat.

Nordin Hussin. (2008). Historical development of coastal ports and towns in the Straits of Malacca. In H. M. Ibrahim \& Hairil Anuar Husin (Eds.), Profile of the Straits of Malacca: Malaysia's perspective (pp. 7-22). Kuala Lumpur: MIMA.

Northern Sea Route Information Office. (n.d.). Retrieved from http://arcticlio.com/

Osborne, M. (2013). Southeast Asia: An Introductory History. Crows Nest: Allen \& Unwin.

Pettersen, T. (2015). Northern Sea Route traffic plummeted. Retrieved from http://barentobserver.com/en/artic

Pinterest (n.d.). Explore North Pole, Grade 2, and more! Pinterest's website. Retrieved from https://www.pinterest.com/pin/42784265770/ 
Ragner, C. L. (2000). Northern Sea Route flows and infrastructure-present Present state and future potential. Lysaker: Fridtjof Nansens Institute.

The Arctic. (2018). Retrieved from https://arctic.ru/infrastructure/20180116/7000166.html

The South China Sea is an important world energy trade route (2013, 4 April). U.S. Energy Information Administration (EIA)'s website. Retrieved from https://www.eia.gov/todayienergy/detai/

Toccheto, J. S., Tancredi, L., Araujo, R. Z., \& Noronha, R. S. (2014). Maritime connectivity in the Asia Pacific Region. UFRGSMUN /UFRGS Model United Nations, 2, 13-80.

Trace, K., Frielink, B., \& Hew, D. (2009). Maritime connectivity in Archipelagic Southeast Asia: An Overview. ADB Working Papers. Manila: ADB.

United Nations Conference on Trade and Development (UNCTAD). (2016). Review of Maritime Transport 2016. New York: UNCTAD.

United Nations Conference on Trade and Development (UNCTAD). (2017). Review of Maritime Transport 2017. New York: UNCTAD.

Urban Gallery. (n.d.). Main maritime shipping routes. Urban Gallery's website. Retrieved from http://urban-gallery.net/tssr/wpcontent/uploads/2013/05/Main-Maritime-Shipping-Routes-800x565.jpg

Wijeratne, D., \& Clayton, E. (2018). The future of ASEAN-Time to act-. Kuala Lumpur: PWC Growth Markets Centre.

Yu, H.-C., \& James, B. (2017). Future of traffic on the Northern Sea Route. Frontier Energy. Retrieved from http://www.frontierenergy.info 